\title{
P53 Mutation in Acute T Cell Lymphoblastic Leukemia Is of Somatic Origin and Is Stable during Establishment of T Cell Acute Lymphoblastic Leukemia Cell Lines
}

\author{
Jo Yeargin, ${ }^{*}$ Jian Cheng, ${ }^{*}$ Alice L. Yu, ${ }^{\star}$ Ruth Gjerset, ${ }^{*}$ Mark Bogart, ${ }^{5}$ and Martin Haas ${ }^{*}$ \\ ${ }^{*}$ University of California San Diego Cancer Center, Departments of Pathology, Biology, ${ }^{\ddagger}$ Pediatrics, and ${ }^{\S}$ Genetics, \\ University of California, San Diego, La Jolla, California 92093-0063
}

\begin{abstract}
Samples donated by patients with $T$ cell acute lymphoblastic leukemia (T-ALL) were screened for mutations of the p53 tumor suppressor gene. Peripheral blood cells of T-ALL relapse patient H.A. were found to possess a heterozygous point mutation at codon 175 of the p53 gene. To determine whether this was an inherited mutation, a B cell line (HABL) was established. Leukemic T cell lines (HATL) were concurrently established by growing peripheral blood leukemic $\mathrm{T}$ cells at low oxygen tension in medium supplemented with IGF-I. Previously we had shown that $>60 \%$ of leukemic $\mathrm{T}$ cell lines possessed mutations in the 533 gene (Cheng, J., and M. Haas. 1990. Mol. Cell. Biol. 10:5502), mutations that might have originated with the donor's leukemic cells, or might have been induced during establishment of the cell lines. To answer whether establishment of the HATL lines was associated with the induction of p53 mutations, cDNAs of the HATL and HABL lines were sequenced. The HATL lines retained the same heterozygous p53 mutation that was present in the patient's leukemic cells. The HABL line lacked p53 mutations. Immunoprecipitation with specific anti-p53 antibodies showed that HATL cells produced p53 proteins of mutant and wild type immunophenotype, while the HABL line synthesized only wild-type p53 protein. The HATL cells had an abnormal karyotype, while the HABL cells possessed a normal diploid karyotype. These experiments suggest that (a) p53 mutation occurred in the leukemic cells of relapse T-ALL patient HA; (b) the mutation was of somatic rather than hereditary origin; (c) the mutation was leukemia associated; and $(d)$ establishment of human leukemia cell lines needs not be associated with in vitro induction of p53 mutations. It may be significant that patient $\mathrm{HA}$ belonged to a category of relapse T-ALL patients in whom a second remission could not be induced. (J. Clin. Invest. 1993. 91:2111-2117.) Key words: acute lymphoblastic leukemia $\bullet$ p53 and $T$ cell acute lymphoblastic leukemia relapse • tumor suppressor gene • establishment of leukemia lines • somatic mutation of p53
\end{abstract}

\section{Introduction}

P53 belongs to the tumor suppressor class of genes (1) whose loss-of-function mutations are oncogenic. Inactivation of the

Address correspondence to Martin Haas, Ph.D., Department of Biology/University of California, San Diego, Cancer Center, 0063, 9500 Gilman Drive, La Jolla, CA 92093-0063.

Received for publication 29 April 1992 and in revised form 15 December 1992.

J. Clin. Invest.

(c) The American Society for Clinical Investigation, Inc. 0021-9738/93/05/2111/07 \$2.00

Volume 91, May 1993, 2111-2117 p53 gene by point mutation, deletion, or rearrangement have been found in a wide range of human tumors. Inactivation of the p53 gene has been demonstrated in human carcinomas of the colorectum $(2)$, lung $(3,4)$, liver $(5,6)$, bladder $(7)$, and ovary $(8)$, in chronic myelogenous leukemias $(9,10)$, in osteogenic sarcomas $(11,12)$, and in T cell acute lymphoblastic leukemias $(T-A L L)^{1}(13,14)$. Since in carcinomas of the colorectum chromosome $17 p$ deletions are associated with the transition from the benign adenomatous to the malignant carcinomatous state, it has been suggested that p53 mutation/ deletion is a late event in the development of cancer (15). However, mutations in p53 have recently been found in adenomatous polyps of patients with familial polyposis coli (16), suggesting that p53 mutation may also occur as an early event in carcinogenesis.

A role for $\mathrm{p} 53$ in the induction and progression of human cancer has been suggested by the status of p53 in individuals with the Li-Fraumeni syndrome, in whom inherited (germline) heterozygous mutations in p53 are associated with a striking predisposition to a number of cancers $(17,18)$. However, in familial leukemia pedigrees hereditary p 53 mutations have not been found (19).

In relapse leukemic $T$ cell lines, both alleles have frequently been found to be independently mutated, rather than one allele being mutated, the other deleted $(15,13)$. As we have proposed previously (13), the high frequency of mutation of all alleles of the p53 gene in leukemic $\mathrm{T}$ cell lines may be due to mutations that have occurred $(a)$ in vitro, $(b)$ in vivo, or $(c)$ both in vivo and in vitro. In previous work (13) we did not determine whether the mutations found in $\mathrm{T}$ leukemia cell lines had resulted from establishment of the lines in culture, as has been shown to occur during the establishment of some rat embryo fibroblast cell lines (20). Alternatively, the high frequency of mutations in p53 in $\mathrm{T}$ leukemia cell lines may be due to the selective establishment of lines from T-ALL cells that already possess p53 mutations in vivo. Presumably, p53 mutations are present in a minority of leukemia cases $(21,14,19)$, but appear in a large fraction of $T$ leukemia cell lines due to the advantage these leukemias have during in vitro establishment. In this scenario the mutations observed in $\mathrm{T}$ leukemia lines would have originated in vivo. A third possibility is that in T-ALL, p53 mutation is not generally found in "diagnosis" T-ALL cases (21), but is associated with the relapse phase, as has been shown for one case (14).

To examine whether $\mathrm{p} 53$ mutations play a role in the morbidity of T-ALL, we explored two mutation "hot spots" in the p53 gene (15) by PCR amplification of genomic DNA and restriction enzyme digestion. One patient (H.A.) was shown to possess a mutation at codon 175 , and this case was studied

1. Abbreviation used in this paper: T-ALL, T cell acute lymphoblastic leukemia. 
further. Our data show that this p53 gene mutation was present in peripheral blood nucleated (leukemia) cells of patient H.A., that the mutation was retained by long-term T-ALL cell lines grown continuously for $>2$ yr from H.A.'s peripheral blood nucleated cells, and that the mutation was somatically acquired. Our experiments also show that additional mutations in the $\mathrm{p} 53$ gene were not induced by establishment of the leukemia cells in vitro.

\section{Methods}

Primary T-ALL samples. Bone marrow, or Ficoll-Hypaque-separated peripheral blood nucleated cells, were frozen live in medium containing $10 \% \mathrm{DMSO}$, at $10^{7} \mathrm{cells} / \mathrm{ml}$ per ampoule. Frozen cells of T-ALL patients were used for all cell cultures and for DNA isolation. Patient cells were donated according to a protocol approved by the Committee on Investigations Involving Human Subjects at the University of California, San Diego, and informed consent was obtained from the patients or their parents. Peripheral blood cells were collected for the purpose of routine clinical diagnosis, and cells that remained after the diagnostic procedures were frozen for future use. T-ALL cells of patient H.A. that were studied in this report were obtained from the patient at first relapse (see below).

Case history. Patient H.A. is a Caucasian girl who was noted to have fever, malaise, and generalized lymphadenopathy at age $7 \mathrm{yr} 2 \mathrm{mo}$. Examination of her peripheral blood showed a white blood cell count of $16.9 \times 10^{9} /$ liter with $90 \%$ lymphoblasts, $8.8 \mathrm{~g} / \mathrm{dl}$ hemoglobin, and $134 \times 10^{9}$ /liter platelets. Bone marrow aspiration showed $98 \%$ blasts, which were positive for CD5 and CD7, and weakly positive for CD4, confirming the diagnosis of acute T lymphoblastic leukemia. She completed a 2-yr course of chemotherapy according to treatment No. 2 of Pediatric Oncology Group protocol No. 8691. It consists of a 6-wk induction regimen with vincristine, prednisone, cyclophosphamide, adriamycin, cytosine arabinoside, and L-asparaginase, followed by 6wk consolidation with VM-26 + cytocine arabinoside and cyclophosphamide + adriamycin + L-asparaginase. This was followed by $10 \mathrm{cy}-$ cles of 9-wk maintenance therapy and weekly L-asparaginase for $20 \mathrm{wk}$. She also received intrathecal treatment with methotrexate + cytosine arabinoside + hydrocortisone for prophylaxis of CNS leukemia.

At age 9 yr 9 mo, 8 mo after the completion of Pediatric Oncology Group protocol No. 8691 treatment, she relapsed with splenomegaly and a white blood count of $17.5 \times 109 /$ liter with $55 \%$ blasts. Cell surface marker analysis revealed similar immunophenotype as at diagnosis. H.A. was then enrolled in Pediatric Oncology Group protocol No. 8862 and underwent reinduction treatment with vincristine, prednisone, daunomycin, and L-asparaginase. At the end of the reinduction her peripheral blasts cleared, but bone marrow contained $63 \%$ blasts. After two courses of intravenous 6-mercaptopurine and methotrexate, she developed marrow aplasia and staphylococcal sepsis. This was followed by resurgence of peripheral blasts and she died of infection $4 \mathrm{mo}$ after relapse.

DNA extraction. One ampoule ( $10^{7}$ live cells) of each frozen T-ALL patient bone marrow or peripheral blood ("primary") sample was lysed in $500 \mu \mathrm{l}$ of lysis buffer (0.5\% SDS, $0.1 \mathrm{M} \mathrm{NaCl}, 50 \mathrm{mM}$ Tris pH 8.0, 1 mM EDTA). $5 \mu$ proteinase $K(10 \mathrm{mg} / \mathrm{ml})$ was added to each sample and samples were incubated at $37^{\circ} \mathrm{C}$ overnight. Samples were then heated at $68^{\circ} \mathrm{C}$ for $5 \mathrm{~min}$, mixed with $75 \mu \mathrm{l}$ of $8 \mathrm{M}$ potassium acetate, extracted once with chloroform, precipitated with ethanol, and dissolved in $300 \mu \mathrm{l}$ of TE buffer. The samples were then treated with DNAase-free RNAase, extracted again with chloroform, reprecipitated with ethanol, and dissolved in a final volume of $\sim 30 \mu \mathrm{l}$ TE buffer.

DNA sequencing. Solid-phase sequencing of in vitro amplified genomic DNA was used, in which genomic DNA was amplified by PCR using biotinylated primers. $1 \mu \mathrm{g}$ of genomic DNA was used as template in a $100-\mu 1$ PCR reaction with 12 pmol of biotinylated primer JY3 (5'-CAACCAGCCCTGTCGTCTCT-3') and 36 pmol of nonbiotinylated primer MH22 (5'-CTGTTCACTTGTGCCCTGAC-3'). $40 \mu \mathrm{l}$ of this reaction was incubated with magnetic beads conjugated covalently with streptavidin (Dynabeads M280-Strepavidin; Dynal, Oslo, Norway) which were used to selectively immobilize the biotin-labeled PCR product and allow melting of the DNA duplex, followed by elution of the nonlabeled single strand. The immobilized single-stranded DNA was then used as sequencing template using the Sequenase (U.S. Biochemical Corp., Cleveland, Ohio) protocol and an internal primer, MH26 (5'-GACTTTCAACTCTGTCTC-3'). Asymmetric PCR amplification of cDNA and direct sequencing analysis were done as previously described (13).

$P C R$ amplification of genomic DNA. Two independent polymerase chain reactions were carried out for each DNA sample to analyze p53 codons 143 and 175. $1 \mu \mathrm{g}$ of genomic DNA was used in each $100-\mu \mathrm{l}$ reaction. The four PCR primers used and the reaction conditions were as described (15).

Restriction enzyme digestion. The PCR-amplified DNA fragments were digested with restriction enzyme Hhal, fractionated in $8 \%$ polyacrylamide gels, stained with ethidium bromide, and photographed under ultraviolet light.

Metabolic labeling and immunoprecipitation. $5 \times 10^{6}$ cells were labeled for $3 \mathrm{~h}$ in $\left.100 \mu \mathrm{Ci} / \mathrm{ml}{ }^{35} \mathrm{~S}\right]$ methionine $/\left[{ }^{35} \mathrm{~S}\right]$ cysteine (translabel, ICN Biomedicals, Inc., Costa Mesa, CA). Cells were lysed in E1A buffer (250 mM NaCl, $50 \mathrm{mM}$ Hepes, 0.1\% NP40, $1 \%$ aprotinin, 500 $\mu \mathrm{M}$ PMSF, $1 \mathrm{mM}$ EDTA) for $15 \mathrm{~min}$ on ice. The lysate was centrifuged at $100,000 \mathrm{~g}$ for $30 \mathrm{~min}$ and the pellet discarded. Equal amounts of radioactive material were reacted with the specific antibodies G59-12 (Pharmingen, San Diego, CA), PAb 240 (Oncogene Science, Inc., Manhasset, NY; 22), PAb 1620 (23), or the nonrelated (SV40 T-Ag) antibody PAb419 (24) for $4 \mathrm{~h}$ at $4^{\circ} \mathrm{C}$. The immune complexes were collected on immobilized recombinant protein A (Repligen Corp., Cambridge, MA), washed three times with EIA buffer, once with PBS, and boiled for $2 \mathrm{~min}$ in sample buffer. Samples were then loaded on a $10 \%$ SDS-polyacrylamide gel. Half-lives were determined by chasing the radiolabeled cells for appropriate time periods in nonradioactive medium, followed by immunoprecipitation as above. The radioactivity assigned to the $\mathrm{p} 53$ bands was quantitated by direct counting of the gel bands in a scanner, or by densitometry.

Karyotype analysis. Karyotype analysis was done as previously described (13).

$H L A-D R$ analysis. HLA-DR analysis was conducted by reverse slot blot PCR hybridization (25). 75-bp fragments of HLA-DR genes were amplified by $\mathrm{PCR}$, labeled with ${ }^{32} \mathrm{P}$, and hybridized to immobilized allele-specific oligonucleotides, encoding amino acids 67-74 of HLADR $\beta$-chain genes. Allele-specific oligonucleotides for six other HLADRB1 and three HLA-DRB3 genes were included in the analysis. Primer and allele-specific oligonucleotides sequences were deduced from published data $(26,27)$.

\section{Results}

H.A. leukemia cells have a heterozygous point mutation in the p53 gene. Genomic DNA of T-ALL patient samples was screened for point mutations at two "hot spots" of the p53 gene, codons 143 and 175, using PCR analysis. A 111-bp fragment surrounding p53 codon 143 and a 319-bp fragment surrounding p53 codon 175 were amplified and digested with the restriction enzyme Hhal. Some mutations (e.g., GTG $\rightarrow$ GCG, Val $\rightarrow$ Ala) in codon 143 would result in cleavage (with Hhal) of the 111-bp PCR-generated fragment to a 68-bp and a 43-bp fragment (13). Human placenta-derived control DNA as well as patient sample DNA showed the 111-bp uncleaved pattern by Hhal digestion (data not shown), suggesting the absence of this specific mutation in codon 143. Similarly, a mutation within codon 175 would abolish an HhaI site, leading to the cleavage (with Hhal) of the 319-bp PCR-generated fragment into three fragments (of $216 \mathrm{bp}, 67 \mathrm{bp}$, and $36 \mathrm{bp}$ ) instead 
of four fragments (of $216 \mathrm{bp}, 49 \mathrm{bp}, 36 \mathrm{bp}$, and $18 \mathrm{bp}$ ). DNA extracted from peripheral blood nucleated cells of relapse TALL patient H.A. showed five restriction fragments of $216 \mathrm{bp}$, $67 \mathrm{bp}, 49 \mathrm{bp}, 36 \mathrm{bp}$, and $18 \mathrm{bp}$, by Hhal digestion (Fig. 1, lane $1)$, revealing the presence of an apparent heterozygous mutation at codon 175 in the peripheral blood/leukemia cells of patient H.A.

Establishment of $T$ cell and $B$ cell lines from peripheral blood cells of patient $H$.A. The peripheral blood cells of relapse T-ALL patient H.A. contained, in addition to $55 \%$ leukemic blasts, a mixture of other cell types. The heterozygous appearance of the mutation at p53 codon 175 may therefore be due to a mixture of leukemic cells that possess a homozygous mutation at codon 175, and nonleukemic cells that are wild type at that position. Alternatively, the leukemic cells may harbor one mutated p53 allele and one allele that is wild type at codon 175 . Finally, the patient may harbor an inherited heterozygous mutation that is present in all cells of the blood sample.

To examine the nature of the mutation, leukemic $T$ cell lines and an immortal B cell line were established from the same ampoule of frozen peripheral blood cells of HA. Eight independently derived T cell lines HATL were established by growing the cells in the presence of $20 \mathrm{ng} / \mathrm{ml}$ recombinant IGFI in a low oxygen $(5 \%)$ tension $\mathrm{CO}_{2}$ incubator $(28,29)$. The lines were then cloned by end point dilution. The $\mathrm{B}$ cell line HABL was established by transforming the cells with EpsteinBarr virus. The leukemic $T$ cell lines and the immortal B cell line have been maintained in continuous culture for $2 \mathrm{yr}$, and have been frozen and thawed repeatedly (30). The lines share an identical human leukocyte antigen type (DR2,7), as is shown in Fig. 2, suggesting that they were indeed derived from the same individual. The long-term HATL lines have the following differentiation markers: $\mathrm{CD}^{-}, \mathrm{CD}^{-}, \mathrm{CD}^{-}, \mathrm{CD}^{+}$ (62\% of the cells), $\mathrm{CD}^{-}, \mathrm{CD}^{+}(76 \%), \mathrm{CD}^{+} 8^{+}(35 \%), \mathrm{CALLA}^{-}$, and lack B cell markers $\mathrm{CD} 19^{-}, \mathrm{CD}^{-} \mathrm{O}^{-}$, and cytoplasmic $\mathrm{Mu}^{-}$. On the basis of cell surface markers HATL might thus be classified as "pluripotent lymphohematopoietic" cell $(31,32)$. Inter-

\section{6}
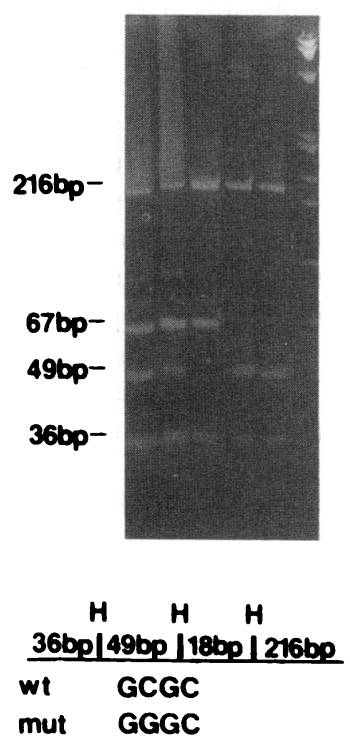

Figure 1. Detection of a mutation at codon 175 of the $\mathrm{p} 53$ gene in blood cell samples of T-ALL patient H.A. Restriction enzyme digestion of PCRamplified fragments from the genomic DNA. Genomic DNA extracted from different cell samples of patient H.A. was amplified by PCR around the $\mathrm{p} 53$ codon 175 region. Amplified DNA fragments were then digested with the restriction enzyme HhaI, fractionated on an $8 \%$ polyacrylamide gel, stained with ethidium bromide, and photographed under ultraviolet light. (Lane 1) Primary peripheral blood nucleated cells of T-ALL patient H.A. (Lane 2) HATL, a clonal leukemia $T$ cell line grown from the peripheral blood of patient H.A. (Lane 3) Cloned DNA sample with homozygous mutation at codon 175 (13). (Lane 4) Wild-type DNA control from a normal human placenta. (Lane 5)
HABL, the immortalized B cell line grown from the peripheral blood of patient H.A. (Lane 6) DNA size marker.

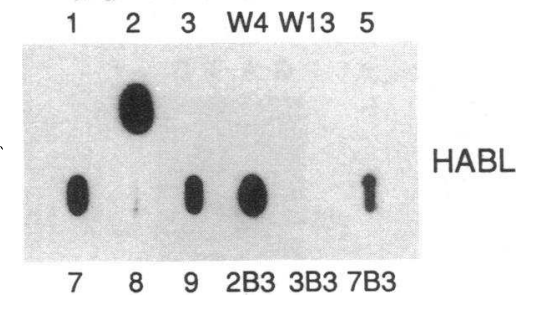

Figure 2. HLA-DR analysis of HATL and HABL cell lines. Reverse slot blot PCR hybridization was used on 75-bp fragments of HLA-DR genes that were PCR amplified, labeled with ${ }^{32} \mathrm{P}$, and hybridized to immobilized allele-specific oligonucleotides encoding amino acids 67-74 of HLA-DR $\beta$-chain genes. The lines are derived from the same individual, and share the DR2,7 specificity.

estingly, the HATL leukemic lines are dependent for growth on exogenously supplied ( $20 \mathrm{ng} / \mathrm{ml})$ IGF-I, and have maintained this dependence for $2 \mathrm{yr}$ of continuous culture. Propagation of the HABL line is independent of exogenously supplied IGF-I.

DNA was extracted both from the HATL and HABL lines, amplified by PCR around codon 175 and digested with Hhal. Fig. 1 (lane 2) shows that HATL cell lines are heterozygously mutated in p53 at codon 175, while the HABL cell line is wild type at the same position (Fig. 1, lane 5) since it possesses the Hhal recognition site, like the wild type control DNA shown in lane 4. Thus, the HATL leukemic cells carry a heterozygous mutation at p53 codon 175 , while the immortalized B cell line established from the same patient carries a homozygous wild type codon at this position. Hence, the heterozygous p53 mutation found in the T-ALL cells of patient H.A. is of somatic rather than hereditary origin.

To examine whether the p53 gene in the leukemic cells of patient H.A. harbor mutations other than the one at codon 175, we sequenced the entire cDNA of several HATL lines. RNA was extracted from HATL cells and reverse transcribed into cDNA. The full length cDNA of HATL cells was then amplified by PCR and directly sequenced as described in Methods. No additional mutations were found in the p53 cDNA of HATL. Full length cDNA of the HABL cell line was also sequenced, confirming the wild type status of the p53 gene in these cells. In addition, exon 5 of genomic DNA from both the HATL and HABL cell lines as well as from the original patient sample was sequenced to verify the $T$ cell origin of the heterozygous point mutation at codon 175 (CGC $\rightarrow$ GGC, Fig. 3). All samples were heterozygous (CGC/CCC, arg/pro) for a known polymorphism at codon 72 (33). The data thus suggest that the HATL cell lines (four have been analyzed), and the primary (in vivo) HA cells from which the lines were derived, harbored only one heterozygous point mutation. Furthermore, in vitro establishment of the HATL lines as well as EBV-induced transformation (immortalization) of the patient's $B$ cells, were not associated with the introduction of additional p53 gene mutations.

Analysis of metabolically labeled p53 proteins in the HATL and $H A B L$ cell lines. $\left[{ }^{35}\right.$ S]methionine-labeled cell lysates of HATL and HABL lines were immunoprecipitated with a panel of antibodies. The G59-12 antibody recognizes both wild type and mutant p53 proteins (30). Fig. 4, lanes 2 and 6 , shows that 
A

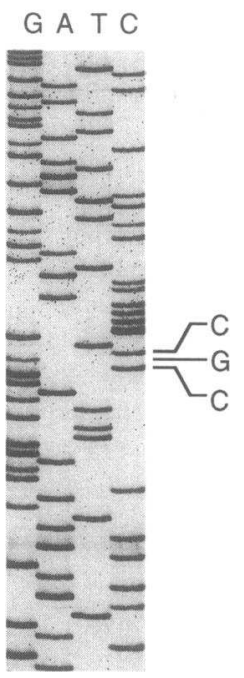

$B$

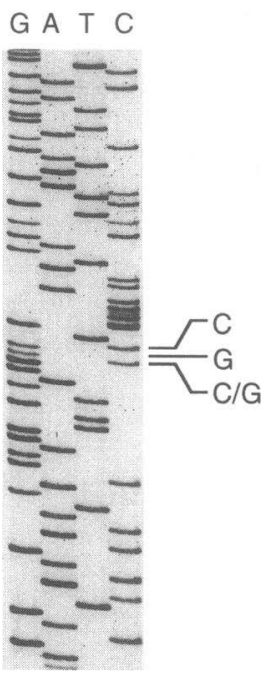

C

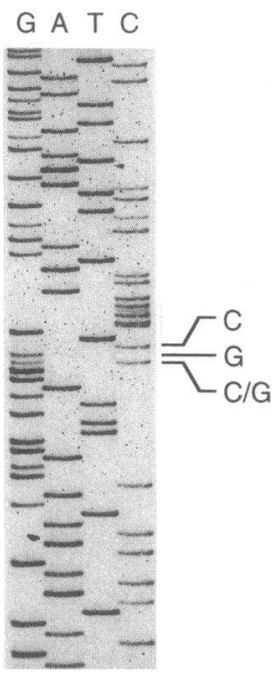

Figure 3. Sequence analysis of exon 5 of genomic DNA from HABL $(A)$ and HATL $(B)$ cell lines and from primary peripheral blood nucleated cells of patient HA $(C)$. DNA was extracted and amplified by PCR using primers JY3 and MH22 and sequenced with internal primer MH26 (see Methods). Shown is the heterozygous mutation found in the p53 sequence at codon 175 in both the patient's peripheral blood sample and in DNA extracted from one of the established HATL cell lines.

this antibody precipitates $\mathrm{p} 53$ protein from both HATL and the HABL lines. The $\mathrm{p} 53$ protein of HA cells have the doubleband pattern characteristic of human cells possessing both polymorphic alleles at codon 72 (33).

Immunoprecipitation with the monoclonal antibody PAb240 (Fig. 4, lanes 3 and 7), which recognizes certain mutant but not wild type forms of $\mathrm{p} 53(22,34,35)$, resulted in the detection of two mutant $\mathrm{p} 53$ proteins in HATL lines, but not of the two wild type p53 proteins of the HABL line, confirming the restriction enzyme and sequencing data of the mutant and wild type status of p53 in either cell type, respectively. PAb

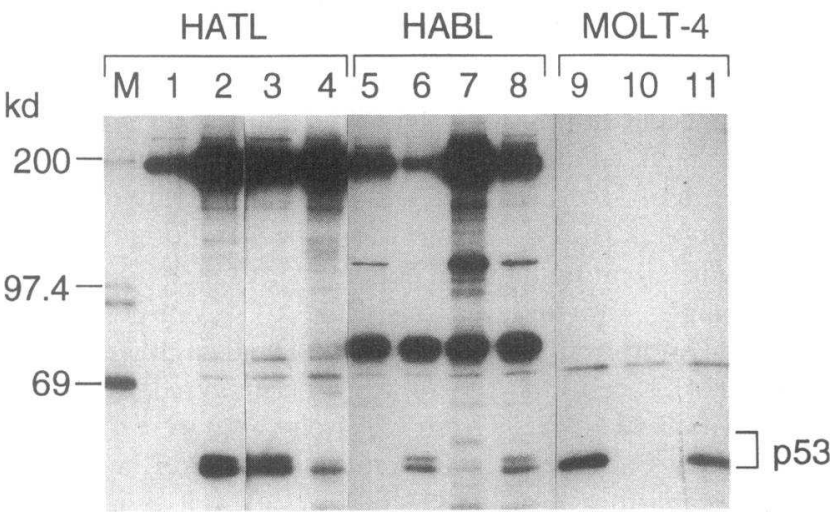

Figure 4. p53 protein analysis of HATL and HABL cell lines. Cells were labeled with $\left[{ }^{35} \mathrm{~S}\right]$ methionine $/\left[{ }^{35} \mathrm{~S}\right]$ cysteine translabel, lysed in E1A buffer, and immunoprecipitated with: (lanes 1 and 5) PAb419, a nonrelevant control antibody; (lanes 2, 6 and 9) G59-12 which recognizes all forms of p53; (lanes 3, 7 and 10) PAb 240, which recognizes certain mutant conformations of the p53 protein; and (lanes 4 , 8 and 11) PAb 1620 which is specific for wild type p53. Immunoprecipitates were analyzed on a $10 \%$ SDS-PAGE gel.
1620 , which recognizes $p 53$ protein in the wild type conformation, precipitated both proteins from the HABL cell line, but recognized only the faster migrating protein from HATL cells (Fig. 4, lanes 4 and 8 ). Lanes 9-11 of Fig. 4 show the immunoprecipitation of $\mathrm{p} 53$ from metabolically labeled Molt-4 T-ALL cells, which we have previously shown to express only wild type p53 (36).

Recognition by PAb240 of both proteins of the HATL cell lines confirms the ability of mutant p53 protein to drive cotranslated wild type $\mathrm{p} 53$ into the mutant conformation, as has been observed in vitro for cotranslated mutant and wild type p53 proteins by Milner and Medcalf (37). Recognition by PAb 1620 of only the faster migrating, codon $72^{\text {arg }}$-containing protein from HATL lines suggests that HATL cells synthesize both wild type and mutant $\mathrm{p} 53$ proteins.

Analysis of the metabolic stability of the $p 53$ proteins in the HATL and HABL cells by pulse-chase experiments (not shown) indicates that both $\mathrm{p} 53$ proteins in HATL cells decay with a half-life of $4.2 \mathrm{~h}$, while the wild type form of p53 in HABL cells has a half-life of $1.2 \mathrm{~h}$. As a comparison, in our hands, $\mathrm{p} 53$ protein in activated (IL-2 grown) normal human peripheral blood T cells turns over with a half-life of $0.5 \mathrm{~h}(36)$.

Karyotype of HATL and HABL cell lines. Karyotype analysis showed that the HABL cells possessed a normal diploid karyotype, while the different HATL isolates had several abnormalities, specifically a clonal rearrangement of chromosome $1 \mathrm{p}$, monosomy 7 , or a rearranged chromosome 7 , but normal chromosomes 17 (the p53 gene maps to human chromosome 17p13). Four examples of karyotypes of HATL cells are shown in Fig. 5.

\section{Discussion}

Several lines of evidence suggest that the development of lymphoid and other hematopoietic neoplasia in humans is associated with alterations of the $p 53$ gene. The presence of high levels of $\mathrm{p} 53$ protein, which is characteristic of tumors harboring mutated $\mathrm{p} 53$ alleles, has been documented in some human lymphoproliferative disorders $(38,39)$, and in blast crisis $\mathrm{CML}$ $(9,10,40,41)$. In $T$ cell leukemias the presence of $\mathrm{p} 53$ mutations has been documented by us (13, and this paper), and others $(14,19)$, though some authors failed to find any such mutations $(21,42)$ in diagnosis T-ALL cells.

6 of 11 human T leukemia cell lines that we have studied possessed independent mutations of $\mathrm{p} 53$ alleles, prompting the question whether the mutations found in these lines may be associated with their establishment rather than being associated with the disease in vivo. This question was particularly acute following the report that establishment of long-term cultures of rat embryo fibroblasts is associated with the induction of p53 mutations (20). Hence, conceivably, p53 mutations found in human $T$ leukemia lines may also have been induced during in vitro establishment.

The present study was designed to examine whether p53 mutations are associated with some T-ALL cases in vivo, whether the mutations are retained in cell lines developed from the leukemias, and whether establishment of $T$ leukemia cell lines is associated with the induction of mutations in p53. Extensive study of the T-ALL relapse patient H.A. now suggests that (a) leukemia cells taken from T-ALL patient H.A. possessed a heterozygous mutation at $\mathrm{p} 53$ codon $175 ;(b)$ the mutation was stable during the establishment of T-ALL lines from 

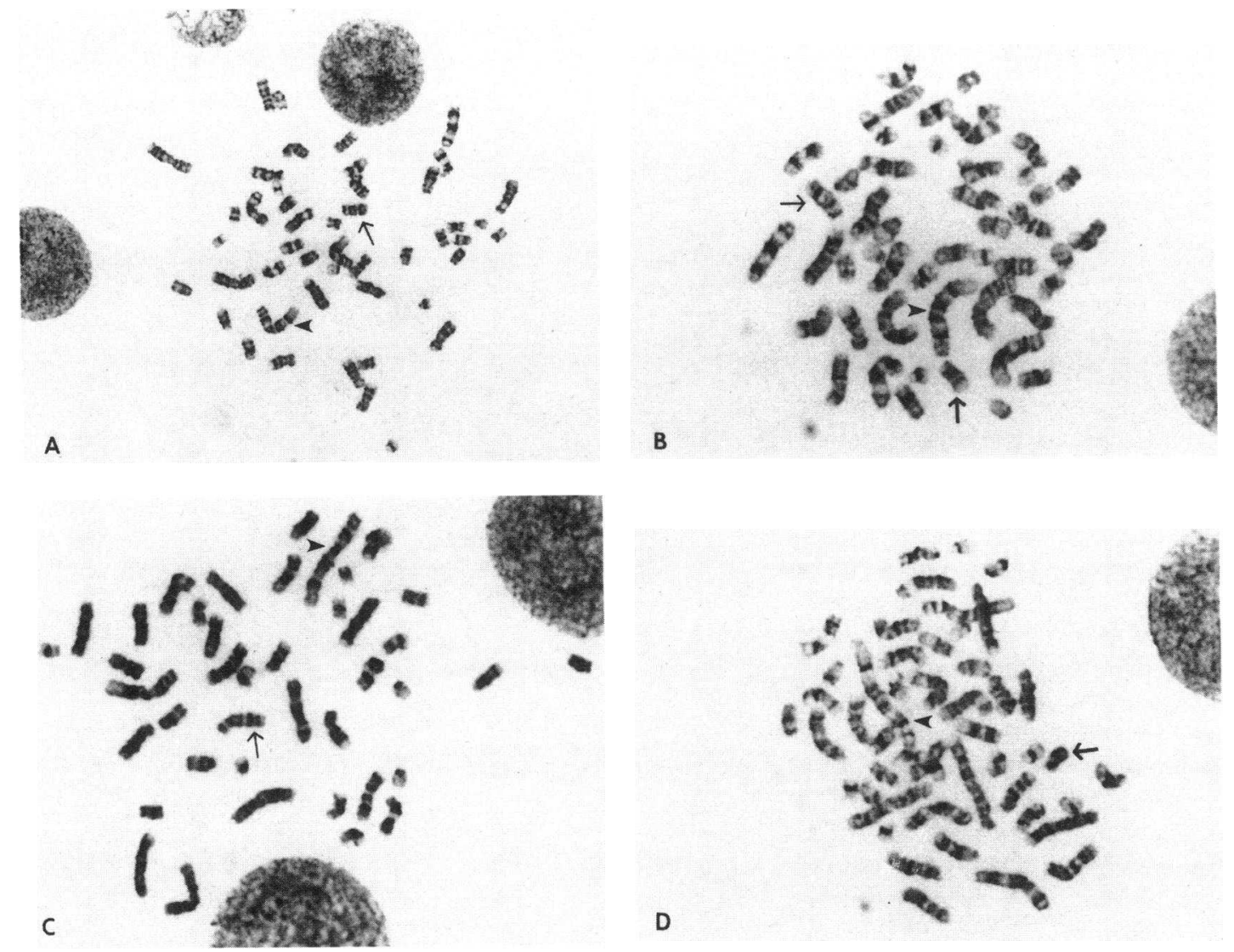

Figure 5. Karyotypes of HATL cells. Four metaphase spreads show the typical chromosome abnormalities observed in HATL cells. All cells analyzed have a structurally rearranged chromosome No. 1 (arrowheads) and monosomy of chromosome No. 7, or $(D)$ a rearranged chromosome No. 7 (thin arrows). In addition, various other, occasional abnormalities have been observed, including trisomy of chromosome No. $18(A)$, and unidentified marker chromosomes (thick arrows in $A$ and $D$ ). The abnormalities shown were present in all eight HATL cell lines studied. The immortalized B cell line HABL has a normal diploid karyotype and is not shown.

the peripheral blood of the patient; $(c)$ establishment of the immortalized (normal) B cell line HABL was not associated with the induction of mutations in $\mathrm{p} 53 ;(d)$ establishment of $\mathrm{T}$ leukemia cell lines HATL was not associated with the induction of additional p 53 mutations; $(e)$ the p 53 mutation in relapse T-ALL patient H.A. was of somatic origin; and $(f)$ patient H.A.'s leukemic $T$ cells resemble the $T$ leukemia lines that we have studied previously (13) with respect to the heterozygous nature of the p 53 mutations, as well as with respect of the absence of loss of heterozygosity.

Our results differ from those of Gaidano et al. (21) and of Jonveaux (42), who suggested that p53 mutations are not implicated in the natural history of T-ALL. These ostensibly discordant sets of data may be resolved in several ways. On the one hand, Gaidano and Jonveaux studied T-ALL diagnosis samples (i.e., samples from early, nontreated cases) which appear not to possess p 53 mutations, while p 53 mutations are associated with relapse T-ALL (this paper, and 14, 19). Furthermore, establishment of T-ALL cell lines has until recently been an infrequent accomplishment $(43,44)$, and establishment of T-ALL lines may have selected for samples harboring p $53 \mathrm{mu}$ tations. Indeed, until recently establishment of T-ALL lines has been limited to relapse cases (45), hence the high frequency of p53 mutations in established cell lines may reflect the situation in relapse cases only. The most reasonable way to reconcile the available data is to suggest that p 53 mutation is infre- quently associated with T-ALL "diagnosis" disease, but is altered during recurrence of the disease; cases that possess p53 mutations have a selective advantage of becoming established cell lines. This interpretation of the available data is in accordance with recent evidence using single-strand conformation polymorphism and direct sequencing analysis of peripheral blood- and bone marrow-derived leukemia samples taken at diagnosis and at relapse. These results indicate that mutations of $\mathrm{p} 53$ are predominantly associated with the relapse phase of the disease (Hsiao, M., J. Yeargin, E. Dorn, A. L. Yu, and M. Haas, manuscript in preparation).

The leukemic cells of patient H.A. were found to possess a heterozygous point mutation at codon 175 ( $\mathrm{Arg} \rightarrow$ Gly). Codon 175 mutations are among the more potently oncogenic p53 mutations, possibly even in the presence of expressed wild type p53 alleles (46). The suppressive action of the wild type allele is thought to be bridled by the mutant allele via a dominant-negative mechanism. Hence, the heterozygous codon 175 mutation found in H.A.'s leukemia cells may have given the cells a distinct growth advantage in spite of the presence of an expressed wild type allele (47). Interestingly, in HATL cells the product of the mutant allele and the majority of the product of the wild type allele possess a mutant immunophenotype on immunoprecipitation gels (Fig. 4; in HATL cells the products of the mutant and of the wild type p 53 allele can be distinguished by their different mobilities on IP gels, due to the polymorphism 
at codon 72 , as the two p53 alleles carry a proline or an arginine at this position, respectively (33).

In HATL cells, the acquisition by the wild type $\mathrm{p} 53$ protein of the mutant immunophenotype under the influence of the mutant $\mathrm{p} 53$ protein may represent a mechanism for the functional inactivation of $\mathrm{p} 53$ by a dominant-negative mechanism (37). This is reminiscent of the data presented by Milner and Medcalf (37) who showed that upon cotranslation in vitro of mutant and wild type p53 alleles the mutant p53 can influence the conformation of the cotranslated wild type $\mathrm{p} 53$ and drive it into the mutant immunophenotype. Imposition of the mutant immunophenotype on the wild type gene product is brought about by the formation of $\mathrm{p} 53$ wild type/mutant complexes, as was documented by Milner (32). Thus the results of immunoprecipitation of metabolically labeled p53 in HATL cells agrees with the in vitro data of Milner and Medcalf on the functional inactivation of $\mathrm{p} 53$ genes by a dominant-negative mechanism.

The mutation in one allele of the p53 gene in HATL cells confers a mutant immunophenotype on much of the wild type protein, encoded by the normal, nonmutated allele. However, as is shown by the karyotype data, mutation of $\mathrm{p} 53$ is not the only abnormality in H.A.'s leukemic cells, and abnormalities in chromosome No. 1 and No. 7 have been found. Indeed, since carcinogenesis is a multistep process, mutation in p53 would not by itself be expected to confer malignancy. Evidence for this notion is amply provided by the state of $\mathrm{p} 53$ in individuals of Li-Fraumeni Syndrome families $(17,18)$. Interestingly, abnormalities in chromosomes Nos. 1, 7, and 17 have been associated with refractoriness to chemotherapy and poor survival in human lymphomas and neuroblastomas $(48,49)$.

Preliminary evidence suggests that mutation of the p53 gene is associated with the recurrence of T-ALL, just as it is associated with the progression of the tumorigenic phenotype of other human tumors. Induction of remission of T-ALL by chemotherapy is more difficult with increasing numbers of relapse episodes. Mutation of the p53 gene therefore appears to point to a poor prognosis of T-ALL, and one would expect that some specific p53 mutations would present a worse prognosis than others. It would be important to determine the relationship between different $\mathrm{p} 53$ mutations and the prognosis of the disease. It would also be important to attempt to suppress the effects of mutated p53 by the introduction of properly-promoted wild type $\mathrm{p} 53$ constructs $(50)$. This laboratory is actively seeking answers in both of these areas (30).

\section{Acknowledgments}

This work was supported in part by grants from the American Cancer Society (CH456), the US Department of Energy (DE-FG03-91 ER61171, and the National Cancer Institute, National Institutes of Health (R01CA56075, and U10CA28439 [to A. L. Yu]), US Department of Health, Education, and Welfare.

\section{References}

1. Finlay, C. A., P. W. Hinds, and A. J. Levine. 1989. The p53 proto-oncogene can act as a suppressor of transformation. Cell. 57:1083-1093.

2. Nigro, J. M., S. J. Baker, A. C. Preisinger, J. M. Jessup, R. Hostetter, K. Cleary, S. H. Bigner, N. Davidson, S. Baylin, P. Devilee, et al. 1989. Mutations in the p53 gene occur in diverse human tumour types. Nature (Lond.). 342:705708.

3. Iggo, R., Gatter, J. Bartek, D. Lane, and A. L. Harris. 1990. Increased expression of mutant forms of p53 oncogene in primary lung cancer. Lancet. 335:675-679.
4. Takahashi, T., M. M. Nau, I. Chiba, M. J. Birrer, R. K. Rosenberg, M. Vinocour, M. Levitt, H. Pass, A. F. Gazdzr, and J. D. Minna. P53: a frequent target for genetic abnormalities in lung cancer. Science (Wash. DC). 246:491494.

5. Bressac, B., M. Kew, J. Wands, and M. Ozturk. 1991. Selective G to T mutations of p53 gene in hepatocellular carcinoma from Southern Africa. Nature (Lond.). 350:429-431.

6. Hsu, I. C., R. A. Metcalf, T. Sun, J. A. Welsh, N. J. Wang, and C. C. Harris. 1991. Mutational hotspot in the p53 gene in human hepatocellular carcinomas. Nature (Lond.). 350:427-428.

7. Sidransky, D., A. Von Eschenbach, Y. C. Tsai, P. Jones, I. Summerhayes, F. Marshall, M. Paul, P. Green, S. R. Hamilton, P. Frost, and B. Vogelstein. 1991. Identification of $\mathrm{p} 53$ gene mutations in bladder cancers and urine samples. Science (Wash. DC). 252:706-709.

8. Marks, J. R., A. M. Davidoff, B. J. Kerns, P. A. Humphrey, J. C. Pence, R. K. Dodge, D. L. Clarke-Pearson, J. D. Iglehart, R. C. Bast, and A. Berchuck. 1991. Overexpression and mutation of p53 in epithelial ovarian cancer. Cancer Res. 51:2979-2984.

9. Ahuja, H., D. Bar-Eli, S. H. Advani, S. Benchimol, and M. J. Cline. 1989. Alterations in the p53 gene and the clonal evolution of the blast crisis of CML. Proc. Natl. Acad. Sci. USA. 86:6783-6787.

10. Kelman, Z., M. Prokocimer, S. Peller, Y. Kahn, G. Rechavi, Y. Manor, A. Cohen, and V. Rotter. 1989. Rearrangements in the p53 gene in Philadelphia chromosome positive chronic myelogenous leukemia. Blood. 74:2318-2324.

11. Diller, L., J. Kassel, C. E. Nelson, M. A. Gryka, G. Litwak, M. Gebhardt, B. Bressac, M. Ozturk, S. J. Baker, B. Vogelstein, and S. H. Friend. 1990. P53 functions as a cell cycle control protein in osteosarcomas. Mol. Cell. Biol. 10:5772-5781.

12. Masuda, H. H., C. Miller, H. P. Koeffler, H. Battifora, and M. J. Cline. 1987. Rearrangement of the p53 gene in human osteogenic carcinomas. Proc. Natl. Acad. Sci. USA. 84:7716-7719.

13. Cheng, J., and M. Haas. 1990. Frequent mutations in the p53 tumor suppressor gene in human leukemia T-cell lines. Mol. Cell. Biol. 10:5502-5509.

14. Felix, C. A., M. M. Nau, T. Takahashi, T. Mitsudomi, I. Chiba, D. G. Poplack, G. H. Reaman, D. E. Cole, J. J. Letterio, J. Whang-Peng, et al. 1992. Hereditary and acquired p53 gene mutations in childhood acute lymphoblastic leukemia. J. Clin. Invest. 89:640-647.

15. Baker, S. J., E. R. Fearon, J. M. Nigro, S. R. Hamilton, A. C. Preisinger, J. M. Jessup, P. vanTuinen, D. H. Ledbetter, D. F. Barker, Y. Nakemura, et al. 1989. Chromosome 17 deletions and p53 gene mutations in colorectal carcinomas. Science (Wash. DC). 244:217-221.

16. Shirasawa, S., K. Urabe, Y. Yanagawa, K. Toshitani, T. Iwama, and T. Sasazuki. 1991. P53 gene mutations in colorectal tumors from patients with familial polyposis coli. Cancer Res. 51:2874-2878.

17. Malkin, D., F. P. Li, L. C. Strong, J. F. Fraumeni, Jr., C. E. Nelson, D. H. Kim, J. Kassel, M. A. Gryka, F. Z. Bischoff, M. A. Tainsky, and S. H. Friend. 1990. Germ line p53 mutations in a familial syndrome of breast cancer, sarcomas, and other neoplasms. Science (Wash. DC). 250:1233-1238.

18. Srivastava, S., Z. Zou, K. Pirollo, W. Blattner, and E. H. Chang. 1990. Germ-line transmission of a mutated p53 gene in a cancer-prone family with Li-Fraumeni syndrome. Nature (Lond.). 348:747-749.

19. Felix, C. A., D. D'Amico, T. Mitsudomi, M. M. Nau, F. P. Li, J. F. Fraumeni, D. E. Cole, J. McCalla, G. H. Reaman, J. Whang-Peng, et al. 1992. Absence of hereditary mutations in ten familial leukemia pedigrees. J. Clin. Invest. 90:653-658.

20. Harvey, D. M., and A. J. Levine. 1991. P53 alteration is a common event in the spontaneous immortalization of primary BALB/c murine embryo fibroblasts. Genes \& Dev. 5:2375-2385.

21. Gaidano, G. P., Ballerini, J. Z. Gong, G. Inghirami, A. Neri, E. W. Newcomb, I. T. Magrath, D. M. Knowles, and R. Dalla-Favera. 1991. P53 mutations in human lymphoid malignancies: association with Burkitt lymphoma and chronic lymphocytic leukemia. Proc. Natl. Acad. Sci. USA. 88:5413-5417.

22. Gannon, J. V., R. Greaves, R. Iggo, and D. P. Lane. 1990. Activating mutations in $\mathrm{p} 53$ produce a common conformational effect. A monoclonal antibody specific for the mutant form. EMBO (Eur. Mol. Biol. Organ.) J. 9:15951602 .

23. Ball, R. K., B. Siegl, S. Quelhorst, G. Brandner, and D. G. Braun. 1984. Monoclonal antibodies against simian virus 40 nuclear large $T$ tumor antigen: epitope mapping, papovavirus cross-reaction and cell surface staining. $E M B O$ (Eur. Mol. Biol. Organ.) J. 3:1485-1491.

24. Harlow, E., L. V. Crawford, D. C. Pim, and N. M. Williamson. 1981. Monoclonal antibodies specific for SV40 tumor antigens. J. Virol. 39:861-869.

25. Saiki, R. K., P. S. Walsh, C. H. Levenson, and H. A. Erlich. 1989. Genetic analysis of amplified DNA with immobilized sequence-specific oligonucleotide probes. Proc. Natl. Acad. Sci. USA. 86:6230-6234.

26. Bell, J. I., D. Denney, L. Foster, T. Belt, J. A. Todd, and H. O. McDevitt. 1987. Allelic variation in the DR subregion of the human major histocompatibility complex. Proc. Natl. Acad. Sci. USA. 84:6234-6238.

27. Gregersen, P. K., M. Shen, Q. Song, P. Merryman, S. Egar, T. Seki, J. 
Maccari, D. Goldberg, H. Murphy, J. Schwenzer, et al. 1986. Molecular diversity of HLA-DR4 haplotypes. Proc. Natl. Acad. Sci. USA. 83:2642-2646.

28. Gjerset, R., J. Yeargin, S. K. Volkman, V. Vila, J. Arya, and M. Haas. 1990. Insulin-like growth factor-I supports proliferation of autocrine thymic lymphoma cells with a pre-T phenotype. J. Immunol. 145:3497-3501.

29. Smith, S. D., P. McFall, R. Morgan, M. Link, F. Hecht, M. Cleary, and J. Sklar. 1989. Long-term growth of malignant thymocytes in vitro. Blood 73:2182-2187.

30. Cheng, J., J.-K. Yee, J. Yeargin, T. Friedman, and M. Haas. 1992. Suppression of acute lymphoblastic leukemia by the human wild-type p53 gene Cancer Res. 52:222-226.

31. Kurtzberg, J., S. H. Bigner, and M. S. Hershfield. 1985. Establishment of the DU.528 human lymphohemopoietic stem cell line. J. Exp. Med. 162:15611578 .

32. Kurtzberg, J., T. A. Waldmann, P. Davey, S. H. Bigner, J. O. Moore, M. S Hershfield, and B. F. Haynes. 1989. $\mathrm{CD}^{+}, \mathrm{CD}^{-}, \mathrm{CD}^{-}$acute leukemia: a syndrome of pluripotent lymphohematopoietic cells. Blood. 73:381-390.

33. Harris, N., E. Brill, O. Shohat, M. Prokocimer, D. Wolf, N. Arai, and V. Rotter. 1986. Molecular basis for heterogeneity of the human p53 protein. $\mathrm{Mol}$. Cell. Biol. 6:4650-4656.

34. Lane, D. P., and L. V. Crawford. 1979. T-antigen is bound to a host protein in SV40-transformed cells. Nature (Lond.). 278:261-263.

35. Varley, J. M., W. J. Brammar, D. P. Lane, J. E. Swallow, C. Dolan, and R. A. Walker. 1991. Loss of chromosome $17 \mathrm{pl} 3$ sequences and mutation of p53 in human breast carcinomas. Oncogene. 6:413-421.

36. Yeargin, J., J. Cheng, and M. Haas. 1992. Role of the p53 tumor suppressor gene in the pathogenesis and in the suppression of acute lymphoblastic T-cell leukemia. Leukemia (Basingstoke). 6(Suppl. 3):85s-91s.

37. Milner, J., and E. A. Medcalf. 1991. Cotranslation of activated mutant p53 with wild type drives the wild type p53 protein into the mutant conformation. Cell. 65:765-774.

38. Koeffler, H. P., C. Miller, M. A. Nicolson, J. Ranyard, and R. A. Bosselman. 1986. Increased expression of p53 protein in human leukemia cells. Proc. Natl. Acad. Sci. USA. 83:4035-4039.

39. Prokocimer, M., M. Shaklai, H. Ben Bassat, D. Wolf, N. Goldfinger, and V. Rotter. 1986. Expression of p53 in human leukemia and lymphoma. Blood. 68:113-118.
40. Feinstein, E., G. Cimino, R. P. Gale, G. Alimena, R. Bertier, K. Kishi, J. Goldman, A. Zaccaria, A. Berrebi, X. P. Mental, et al. 1991. P53 in chronic myelogenous leukemia in acute phase. Proc. Natl. Acad. Sci. USA. 88:62936297.

41. Mashal, R., M. Shtalrid, M. Talpaz, H. Kantariian, L. Smith, M. Beran, A. Cork, J. Trujilo, J. Gutterman, and A. Deisseroth. 1990. Rearrangement and expression of p53 in the chronic phase and blast crisis of chronic myelogenous leukemia. Blood. 75:180-189.

42. Jonveaux, P., and R. Berger. 1991. Infrequent mutations in the p53 gene in primary human $\mathrm{T}$-cell acute lymphoblastic leukemia. Leukemia (Basingstoke). 5:839-840.

43. Hirose, M., K. Minato, K. Toninai, M. Shimoyama, S. Watanabe, T. Abe, and $K$. Deura. 1983. Two novel cultured cell lines, A3/KAWAKAMI and A3/ FUKUDA, derived from malignant lymphoma of $B($ non-T)-cell nature of the gastrointestinal tract. Gann. 74:106-115.

44. Huang, C. C., Y. Hou, L. K. Woods, G. E. Moore, and J. Minowada. 1974 Cytogenetic study of human lymphoid T-cell lines derived from lymphocytic leukemia. J. Natl. Cancer Inst. 53:655-658.

45. Haas, M., A. Yu, and R. Gjerset. 1990. Characteristics of the leukemic cell in childhood acute lymphoblastic T cell leukemia at diagnosis. Leukemia (Basing stoke). 4:230-234.

46. Hinds, P. W., C. A. Finlay, R. S. Quartin, S. J. Baker, E. R. Fearon, B. Vogelstein, and A. J. Levine. 1990. Mutant p53 DNA clones from human colon carcinomas cooperate with ras in transforming primary rat cells: a comparison of the "hot spot" mutant phenotypes. Cell Growth \& Differ. 1:571-580.

47. Chen, P. L., Y. Chen, R. Bookstein, and W. H. Lee. Genetic mechanisms of tumor suppression by the human p53 gene. 1990. Science (Wash. DC). 250:1576-1580.

48. Cabanillas, F., S. Pathak, G. Grant, F. B. Hagemeister, P. McLaughlin, F. Swan, M. A. Rodriguez, J. Trujillo, A. Cork, J. J. Butler, et al. 1989. Refractoriness to chemotherapy and poor survival related to abnormalities of chromosomes 17 and 7 in lymphoma. Am. J. Med. 87:167-172.

49. Brodeur, G. M., and R. L. Saylors III. 1991. Neuroblastoma, retinoblastoma, and brain tumors in children. Curr. Opin. Oncol. 3:485-496.

50. Mercer, W. E., M. T. Shields, M. Amin, G. J. Sauve, E. Appella, J. W. Romano, and S. J. Ullrich. 1990. Negative growth regulation in a glioblastoma tumor cell line that conditionally expresses human wild-type p53. Proc. Natl. Acad. Sci. USA. 87:6166-6170. 